of coalition formation and agenda manipulation. Among the best known, in addition to The Theory of Political Coalitions and Liberalism against Populism, are his papers "Implications from the Disequilibrium of Majority Rule for the Study of Institutions" (APSR 1980 ), which raised a fundamental question about how we understand the stability of institutions; "A Theory of the Calculus of Voting" (APSR 1968, with P. Ordeshook), on the motivations for rational participation; "Bargaining in ThreePerson Games" (APSR 1967), one of the first efforts at experimental testing of rational choice models in political science; and “Arrow's Theorem and Some Examples of the Paradox of Voting" (in Claunch, ed., Mathematical Applications in Political Science I, 1965), exhibiting legislative manifestations of majority voting cycles. These works have encouraged and shaped several generations of scholarship in formal theory.

While the path-breaking work by Riker and his students in formal theory will no doubt remain his most remarkable contribution, Bill Riker was deeply interested in empirical and normative scholarship as well. From his early detailed case studies of decision making by the National Labor Relations Board, through his work on federalism, Congressional roll-call voting, railroad abandonment and air transport deregulation, to the studies of the ratification of the American Constitution that occupied much of his time during the last decade, Bill Riker was fascinated by the events of politics and used his formidable analytic powers to explain them. The charming series of applications of rational choice analysis to historic (and even fictitious) events in The Art of Political Manipulation represent Bill Riker's wide-ranging empirical interests in a vein intended to amuse as well as instruct. Moreover, he seldom neglected for long the great normative issues of democracy and (as in Liberalism Against Populism) continually pressed to understand how our growing knowledge of the nature of social choice shaped our very formulation of these issues.
During the course of his lengthy career, he received many honors. He was elected to the American Academy of Arts and Sciences and to the National Academy of Sciences; he served as president of the American Political Science Association in 1982-83; he co-founded the Public Choice Society, and served as its president from 1965 to 1967. A Guggenheim Fellow, he received honorary degrees from Lawrence University, Depauw University, SUNY Stony Brook, and the University of Uppsala in Sweden. A vital and inspiring teacher, he received three awards for teaching, the Uihlein Prize at Lawrence University, and the Edward Peck Curtis Awards both for undergraduate and for graduate teaching at the University of Rochester. He also served as Rochester's University Dean of Graduate Studies and as a member of the City of Rochester zoning board.

Although he retired in a technical sense in 1991, Riker continued to teach and to do research full time. At the time of his death, a book he had edited, Agenda Formation, had just been published, and he had completed a book manuscript, Rhetorical Interaction in the Ratification Campaign. He was also deeply involved in a project investigating the creation and protection of property rights, with special emphasis on developments in East Europe and the former Soviet Union. He was planning, and looking forward with characteristic relish, to spending part of the summer in South Korea, where he had been invited to advise the government on the subject of federalism.

In his colleagues' eyes, however, Bill Riker's considerable skills as an institution-builder, teacher, and social scientist could never overshadow his qualities as a colleague and mentor. His energy and enthusiasm were infectious; his commitment to political science exemplary; and his store of knowledge aweinspiring. He had time for every colleague and every student, and a knack for the encouraging word that continually spurred us on. Bill's influence on each of us, like his influence on the department and the discipline, will prove longlasting.

Survivors include his wife, Mary Elizabeth Riker of Rochester; a son, William H. Riker, Jr., of Providence, Rhode Island; two daughters, Katharine Riker of Portland, Oregon, and Mary Paris Riker, of Chico, California; and three grandchildren. Another son, Benjamin, predeceased him.

Memorial contributions may be made to the William H. Riker Fund at the Department of Political Science, University of Rochester. An effort is presently under way to create an annual William H. Riker Memorial Prize and Lecture to recognize outstanding achievements in the study of politics; contributions to the Riker Fund will be used toward endowing this prize.

Randall Calvert

John Mueller

G. Bingham Powell

University of Rochester

\section{Arthur Bruce Winter}

Arthur Bruce Winter, Professor Emeritus, Political Science Department, University of Nebraska-Lincoln, died at home in Lincoln, Nebraska on October 6, 1993. He was 75 years old and had been retired for five years.

Born in Mount Vernon, New York, Bruce was on active duty with the U.S. Navy on December 7, 1941. He served for the duration of World War II, having been commissioned as an officer in 1944. After separation from the service, he remained active in the Naval Reserve.

He received a BA in Political Science from Emory University in 1946 and an MS in Government Management from the University of Denver in 1948. His PhD, awarded in 1955, was from Duke University. Bruce began his career as a research associate in the Bureau of Public Administration at the University of Tennessee. In 1954, he accepted a position with the University of Nebraska and remained with the department until his retirement in 1989.

For twenty years, he was direc- 
tor of the Government Research Institute at UNL. During that time, he and his research assistants produced a large number of monographs and bulletins directed to specific problems of municipal government in Nebraska. No one in the state had a surer grasp of the complexities of local government and administration than Bruce Winter and through his close association with the Nebraska League of Municipalities, he was a principal conduit for the translation of political science research for the practitioners.

But Bruce's first love was teaching and research in the field of con- stitutional law. In fact, he insisted that his students love the law as much as he did. Three decades of pre-law majors were introduced to the majesty of the law through his rigorous methods of instruction. Many of those students, we are sure, still regard his classes with a combination of awe and admiration. In recognition of his ability in the classroom, he was presented with a distinguished teaching award before his retirement.

Bruce was for 35 years a ferocious defender of academic freedom and the prerogatives of the professoriat. He always insisted that a university was a community of scholars and not just one more bureaucracy. Many administrators here felt his wrath when be believed that rules and regulations were intruding into that community.

Among lesser claims to fame, Bruce was probably the last person at this university to drive to work regularly in a Studebaker, a car he lovingly maintained.

The colleagues, former students, and friends of Bruce Winter mourn his death. His contributions to the university and the state will be long remembered.

Robert D. Miewald University of Nebraska-Lincoln 